\title{
REVIEW ON SOCIAL ENTREPRENEURSHIP
}

\author{
Sh. Sachin Gupta
}

SOMC, Sanskriti University, Mathura, Uttar Pradesh, India

\begin{tabular}{|c|c|c|}
\hline Journal & \multicolumn{2}{|c|}{$\begin{array}{l}\text { Samvakti Journal of Research in Business Management } \\
\text { https://www.sjrbm.samvaktijournals.com } \\
\text { Volume } 2 \text { Year of Volume } 2021 \text { Page No }: 17-24\end{array}$} \\
\hline Discipline & \multicolumn{2}{|l|}{ Business Management } \\
\hline Conference & \multicolumn{2}{|c|}{$\begin{array}{l}\text { A virtual international conference on redefining and transforming the role of higher } \\
\text { education in sustainable development }\end{array}$} \\
\hline Conference & \multicolumn{2}{|l|}{ Start Date: September 30, 2021} \\
\hline Dates & \multicolumn{2}{|l|}{ End Date : September 30, 2021} \\
\hline Institute Name & \multicolumn{2}{|c|}{$\begin{array}{l}\text { JAIN (Deemed-to-be University) in association with Council for Industrial } \\
\text { Innovation and Research }\end{array}$} \\
\hline $\begin{array}{l}\text { Date Received } \\
\text { ID } \\
\text { Dol }\end{array}$ & $\begin{array}{ll}: \text { November 19, 2021 } & \begin{array}{l}\text { Publication Date } \\
: 2021.01 .14\end{array} \\
: 10.46402 / 2021.01 .14 & \text { Paper Type } \\
\text { Dol URL }\end{array}$ & $\begin{array}{l}\text { : December } 12,2021 \\
\text { : Conference Paper } \\
: \text { https://dx.doi.org/10.46402/2021.01.14 }\end{array}$ \\
\hline
\end{tabular}

\section{ABSTRACT}

This article examines the notion of "social entrepreneurship" in its widespread use from an analytic, critical, and creative standpoint, taking into account either the "social" and the "entrepreneurship" aspects of the term. There is a wide variety of usage on both points, with substantial variations characterized by factors like the importance of social objectives or what are considered to be the prominent characteristics of entrepreneurship. The study can conclude with a proposition for a more flexible definition of social entrepreneurship: social entrepreneurship is practiced when one or more people (1) seek to create value in society or some kind of, whether exclusively or prominently, and seek that goal through a combination of (2) just like opportunity to generate this value, (3) utilizing innovation, and (4) tolerating risk.

KEYWORDS: Entrepreneurship, Employing, Innovative, Resources, Social.

\section{INTRODUCTION}

Ideas of societal entrepreneurship are gained traction in a corporate world. The features of companies believed to participate in social entrepreneurship have been the subject of popular and academic books and articles. It is taught in many top business colleges 
curricula, and this is the topic of many academic and specialized conferences. There are organizations dedicated to researching and implementing social entrepreneurship, as well as a plethora of websites where one can learn more about the idea and get information and/or guidance on how to put it into reality. There are also entire issues of prestigious business magazines devoted to the field of social entrepreneurship, such as this one.

Anyone who takes a look at this collection of materials may be perplexed as to social entrepreneurship is. Is it fair the use of the solid business methods to management of non-profit organizations, as just some claim, or is it a more radical departure from the commerce of doing good? What is it about this strategy that makes it so appealing? Understanding what the phenomena, in fact, is a necessary element of addressing these concerns. It is understood in a number of ways by commentators, both academic and popular, and supporters of all kinds. Just to make such remarks and lobbying understandable, the idea has to be explained. Other, more applied reasons exist for deficient to be explicit around the social entrepreneurship entails. For one of the reason, when contrasted to traditional types of business, social innovation may need quite different criteria of assessment. If there are reason to think that social entrepreneurship is a viable tool for solving the social problems, further assistance in the form of laws and many other types of social strategy may be required.

Finally, it's probable that set of managerial abilities necessary for an effective social venture differs greatly from those required for traditional business. This work doesn't really attempt to address these crucial issues, that keep pointing to use of more study. It is, nevertheless, intended to meet an essential requirement of dealing with such issues. It's critical to understand what social entrepreneurship entails. This article focuses on this important job. To instigate, the theoretical landscape of "social free enterprise," as that word is often used, is examined ${ }^{[1]}$. As a result, the article starts with an analytic and "reportive" investigation. Learned suggestions for the concept's substance are examined, as well as less reflective applications of the concept, with the former often being compared to the latter. The main goal is to figure out what features of a certain action are expressly or indirectly associated with the term "social entrepreneurship." As previously stated, the research displays a number of distinct applications grouped into two categories: one dealing with the social aspect of the idea, and the other with the business aspect. As a result, a crucial and synthetic component has been included to this research. The rationale for retaining a degree of permissiveness in the concept while excluding specific areas of usage that render the concept inadequately discriminating will be discussed. As a result, a suitable flexible explanation of the idea is suggested at the end of the article; one that collects some fundamental components inherent in common use while eliminating certain others who also expand its applicability to the point where it is barely selective. ${ }^{[2]}$. 
The link between social entrepreneur or what is known described as "social enterprise" has been assumed in the this essay. As seen by several quotations, enterprise (typically phrased without a definitive or indeterminate article) is commonly confused with social enterprises. For the point of this article, we'll disregard the similarities. It is assumed that discussing the notion of social entrepreneurship implies lighting the definition of social company as a company in what following, and previous writers' habit of accurately utilizing the terminology is followed. The link among entrepreneurs businesses, or particular organizations or organizations, is much more nuanced, but it will be preserved at a theoretical level for the purpose of study. ${ }^{[3]}$.

\section{DISCUSSION}

\section{The feeling of "minimalist":}

In the general media, the term "businessperson" is often used in a very crude manner. A small company owner or entrepreneur is merely someone who establishes and/or manages a small business. This use is reflected in several definitions. For example, according to the Canadian Oxford Dictionary, an businessperson is "a person that begins or systematizes a business company, particularly one containing financial risk". This is what one could term a "minimalist" view of entrepreneurship. A social entrepreneur will be defined somebody who develops and/or runs an enterprise or company with social objectives in one of the methods explained later in this article ${ }^{[4]}$.

\section{The approach of "business techniques":}

As shown in a slightly extended but still "common" concept, the enterprising part of social enterprise is intimately linked with borrowing first from viewpoint and practices of commerce "Entrepreneurship is defined as the act of starting a firm. "The key to social enterprise is to tackle the objective of offering community resources in a businesslike, innovative manner." "According to Operant, The formation of new socially responsible firm companies is one facet of social enterprise. Another aspect is increasing income production from programs by using for-profit business concepts while remaining true to the primary purpose. Many stories in the news, as well as training materials used by nonprofits and others, show this focus on "business techniques"[5].

\section{In favor of a more refined understanding:}

Those who focus on the entrepreneurial aspect of social entrepreneurship, on the other hand, are more likely to rely on academic context of entrepreneurship and adapt it to the social realm. As a consequence, the entrepreneurial component of social enterprise has a more rigorous definition. This is, in my opinion, the better way to understand business in overall and communal entrepreneur in specific. In describing the concept's current 
variety of applications, it's important to note that social entrepreneurship is often interpreted simply as creation and/or administration of a social business, maybe with certain unambiguous awareness of the dangers associated.

The more specific definition appears to include elements that make the entrepreneurial spirit, particularly social enterprise, a useful cognitive tool. The thesis of this paper is that the most takes note of the foundational means allowing for the identifier of a collective of individuals or groups within the skin of those who discharge or administer (social) businesses who would have the way to generate significant value, mostly in a shorter time, and therefore make unusual contributions to society of corporate in then they are engaged. We don't pretend that academic research results in a neat description with a very well set of individually necessary and together adequate criteria. Instead, the study refers to a number of traits that may be combined or weighted in many ways, but are favorably relevant when considering anyone as an entrepreneurial. As a consequence, there is a much more fluid, yet still broad, interpretation of the function of the entrepreneur. ${ }^{[6]}$.

\section{Commendable entrepreneurs:}

The form of organizational business proposed by Mort, Weerawardena, and Carnegie is possibly the most complicated. They feel that community enterprise is a construct made up of a variety of distinct characteristics. They suggest that society company owners "show a measured judgment, a coherent unity of goal and behavior in the midst of complication," citing a range of research studies on business to back up their claim. Researchers argue that this tendency helps the entrepreneurial to balance the needs of several customers whilst preserving a strong sense of purpose even when moral dilemmas exists. Second, businesspersons are masters at seeing and seizing chances to provide the social benefit they seek in a more effective manner. Finally, social entrepreneurs demonstrate the same, ingenuity, risk-tolerance and reactiveness that profitable tycoons do in their industry ${ }^{[7]}$.

At smallest one of the characteristics in this list goes beyond what is recommended in previous social business uses of the idea of entrepreneurship. The concepts of stable ruling and consistency of purpose are added to the previously discussed concepts of chance identification, risk tolerance, inventiveness, and resourcefulness. This idea highlights a general problem with elucidating the notion of entrepreneurship, maybe particularly when it is used to a social purpose. With the this suggestion, Mort et al. may have shifted beyond identifying a successful enterprise to characterizing a reputable or great social businessman and expanded on that notion using principles of virtues in ethics.) There appear to be hints of this trend even now in Dees' more limited list (1998). He describes an entrepreneur, for example, as somebody who "tirelessly" explores new methods and further the social mission and engages in "continuous" invention. ${ }^{[8]}$. 
Here is widespread contract that innovation processes their endeavors are motivated by social objectives, or the wish to help society in some manner. This is additional method of stating that a social entrepreneur seeks to enhance "social value," or donate to the well-being or well-being of a particular hominid society, in some manner. Disagreement arises about the importance of social objectives in the goals of the entrepreneur or his/her venture.

\section{What about other objectives? If so, how prominent will it be:}

Profitability seems to be compatible with social entrepreneurship in the examples mentioned above, although aims continue to dominate the goal structure of these enterprises.

n 2004, Ben \& Jerry's, a very successful company, gave more than $\$ 1.1$ million to charity organizations. "Is it just flavour with an elegant heaping helping of csr initiatives or, as its forbearers suggested, is it just pastry with an elegant dollop of business ethics or, as its progenitor cells proposed, is it just flavour with an elegant good amount of csr initiatives or, as its forbearers suggested, is this just pastry with a stylish dollop of corporate ethics or, as its progenitors recommended, is it just dessert with a stylish is it also social entrepreneurial spirit? It seems that denying it such rank is tough. The stated mission of Ben \& Jerry's Handmade Holdings Inc. blends a strong commitment to commerce with an extremely high social and environmental awareness. The company's performance seems to reflect these promises.

\section{Only social objectives and non-profit status:}

Those who believe that a social entrepreneur's only objective must be to achieve some social goal(s) are at one level. 'For communal entrepreneurs, the communal purpose is clear and essential.... Mission-related effect becomes the primary criteria, not money generation," says Dees (1998), a social entrepreneurship researcher. For social entrepreneurs, wealth is just a means to a goal. The notion that any money produced is just a incomes to a communal purpose implies that monetary gain for the businessperson is not one of the undertaking's objectives.

\section{Adding profit to a organization is a step beyond the status}

There are strong reasons to not limit the concept to non-profit organizations. For one reason, the distinction between -profit and non-profit for organizations is far from clear. One helpful effort to define the NFP sector comes from an Australian review panel: "A not-for-profit organization... is one that is forbidden from transferring profits to its membership, owners, or managers by its governing rules or regulations". 
Even with this reasonable prescription, there are instances that seem to be on the edge. Even if it is believed that the firm's governing laws prohibit anything other, calling the business a non-profit organization may appear a stretch. Instead, it seems weird to lump Howard's Itself in with all the for-profit enterprises, even if the charity distribution is exclusively due to benevolence rather than company law. However, there's really unanimous consensus that Howard's Way, as far as it counts as an instance of business, must be regarded as social enterprise.. As a result, there are instances when the profit/non-profit distinction is blurred. And this may lead to the conclusion that the border isn't all that essential ${ }^{[0][10]}$.

\section{CONCLUSION}

This paper proposes that social entrepreneurship is practiced when someone and a group: (1) focuses on creating value in society, either solely or prominently; (2) demonstrates a capability to comprehend and exploit opportunities to create that value ("envision"); and (3) employs advancement, ranging from out and out invention to a combination of the above. The first of these requirements is the most significant since it fundamentally distinguishes social entrepreneurship from other types. There is no precise line at which the significance of social objectives becomes insufficient to classify anything as social entrepreneurship. The distinction between social and other types of entrepreneurs is defined by a dedication to delivering social benefit. All of the aforementioned qualities are traits that may be possessed to varying degrees. Some are defined as being "greater than normal" in terms of quantity, but there is no means of knowing when this qualifying criterion is met or surpassed. This list, like the social element of the target idea, provides a catalog from which specific users of the idea will choose what they include and how they weight the variables.

Even with the "precising" method to definition used in this study, this unpredictability may be attributed to the lack of clear boundaries in the phenomenon. This insight leads to one clear piece of advise. Anyone who uses the term "social private enterprise" should makes it strong what meaning he or she has to it. In discussing social and other kinds of entrepreneurship, the summary makes a significant divergence from something often assumed. It's tempting to assume, and the research often appears to confirm, that social free enterprise is done by people. It would be a mistake, as Thompson points out, to receive this assumption.

Enterprise is best viewed as a long mission that may be undertaken by a group or groups of people. The qualities stated above may be seen as positions in a production, with duties that can be distributed and/or split. Others here have stated that business thrives in environments where community thought is valued above individual understanding. Peredo presents a scenario in which it is reasonable to talk of a society working 
collectively to engage in a kind of entrepreneurship that is clearly social in many ways. As a result, being an entrepreneurial may refer to a person, a group, or an organization that is responsible for recognizing and creatively pursuing a societal objective. 


\section{REFERENCES}

[1] O. M. Lehner and J. Kaniskas, "Opportunity recognition in social entrepreneurship: A thematic meta analysis," J. Entrep., 2012, doi: 10.1177/097135571102100102.

[2] A. W. Montgomery, P. A. Dacin, and M. T. Dacin, "Collective Social Entrepreneurship: Collaboratively Shaping Social Good," J. Bus. Ethics, 2012, doi: 10.1007/s10551-012-1501-5.

[3] J. G. Dees, "A Tale of Two Cultures: Charity, Problem Solving, and the Future of Social Entrepreneurship," J. Bus. Ethics, 2012, doi: 10.1007/s10551-012-1412-5.

[4] T. Grimes, M., McMullen, J., Vogus, T., Miller, "Studying the Origins of Social Entrepreneurship: Compassion and Does Compassion Matter to Social Entrepreneurship," Acad. Manag. Rev., 2012.

[5] K. K. Wiley and F. S. Berry, "Teaching Social Entrepreneurship in Public Affairs Programs: A Review of Social Entrepreneurship Courses in the Top 30 U. S. Public Administration and Affairs Programs," J. Public Aff. Educ., 2015, doi: 10.1080/15236803.2015.12002205.

[6] S. Dorado and M. J. Ventresca, "Crescive entrepreneurship in complex social problems: Institutional conditions for entrepreneurial engagement," J. Bus. Ventur., 2013, doi: 10.1016/j.jbusvent.2012.02.002.

[7] J. Meewella and M. Sandhu, "Commercial benefits of social entrepreneurship," World Review of Entrepreneurship, Management and Sustainable Development. 2012, doi: 10.1504/WREMSD.2012.049394.

[8] "Business Models in Social Entrepreneurship: An Approach to Typology Building," Russ. Manag. J., 2018, doi: 10.21638/spbu18.2018.205.

[9] S. Wood, "Prone to progress: Using personality to identify supporters of innovative social entrepreneurship," J. Public Policy Mark., 2012, doi: 10.1509/jppm.11.060.

[10] A. Huq and D. H. Gilbert, "Enhancing graduate employability through work-based learning in social entrepreneurship: A case study," Educ. Train., 2013, doi: 10.1108/ET-04-2012-0047.

\section{$\underline{\underline{E N D}}$}

